\title{
EXPERIMENTAL INVESTIGATION OF THE THERMAL PERFORMANCE OF A TWO- PHASE CLOSED THERMOSYPHON AT DIFFERENT OPERATING CONDITIONS
}

\author{
Engin Gedik* \\ Energy Systems Engineering Department, Faculty of Technology, Karabük University, TR-78050, \\ Karabük, Turkey \\ *Corresponding Author \\ Tel:+(90) 370-4338200, Fax:+(90) 370-4338204, e-mail: egedik@ karabuk.edu.tr
}

\begin{abstract}
In this study, the thermal performance of a two-phase, closed thermosyphon (TPCT) was investigated experimentally. In the experiments, we used water, ethanol, and ethylene glycol as the working fluids and considered different operating conditions, such as inclination angles $\left(30,60\right.$, and $\left.90^{\circ}\right)$, heat inputs $(200,400$, and $600 \mathrm{~W})$, and flow rates of cooling water (10, 20, and $30 \mathrm{~L} / \mathrm{h})$. Initially, an experimental test rig was designed and built, and, then, a series of rigorous tests was conducted on the TPCT. In the experiments, the temperature distribution on the wickless heat pipe or the thermosyphon's surface and the temperature differences of the cooling water were measured. The data were used to calculate the thermal resistance and efficiency of the TPCT, and the results are presented graphically and discussed in detail. The efficiency of the TPCT for each working fluid at different operating conditions varied between averages of 30 and 95\%, which was in good agreement with published results. The results indicated that water was the best working fluid when the heat inputs were $200 \mathrm{~W}$ and the flow rates of the cooling water were $10 \mathrm{~L} / \mathrm{h}$. Ethylene glycol was the best working fluid when the heat inputs were $200 \mathrm{~W}$ and the flow rates of the cooling water were $30 \mathrm{~L} / \mathrm{h}$. Ethanol was the best working fluid when the heat inputs were $600 \mathrm{~W}$ and the flow rates of the cooling water were $10 \mathrm{~L} / \mathrm{h}$. In addition, it was found that the inclination angle and heat inputs had significant effects on the efficiency of the TPCT.
\end{abstract}

Keywords: thermosyphon, wickless heat pipe, two phase, water, ethanol, ethylene glycol. 


\section{Introduction}

Because heat transfer is an integral part of many industrial processes, these processes perform more efficiently when the heat transfer rates are appropriate for the intended application. The increasing rate of energy consumption in today's world has caused engineers and scientists to focus more attention and effort on developing new energy technologies and thermal management systems. Thus, the efficient use of existing energy technologies has become an important and serious issue. However, large quantities of energy are being lost by thermal systems, and heat exchanger devices are being used to recover this energy and put it to beneficial use in heating and cooling processes. Among these devices, the heat pipe which can transport relatively a large quantity of energy over a small temperature gradient between its ends is preferred in thermal systems [1].

A heat pipe is a two-phase, heat-transfer device that is vacuumed a closed volume, and it can have a cylindrical shape or various other shapes. Due to their excellent heat transfer capabilities [2], heat pipes are superior heat exchangers, and they are used extensively in various industrial applications, such as adsorption, refrigeration, computer systems, water heater systems, seawater desalination, ground source heat pumps, and space applications [3]. Some types of heat pipes that are in general use were described in $[4,5]$ as follows, i.e., i) variable conductance heat pipes, ii) thermal diodes, iii) oscillating heat pipes (OHPs), iv) loop heat pipes (LHPs) and capillary pumped loops (CPLs), v) micro heat pipes, vi) heat pipes that use electrokinetic force, vii) rotating heat pipes, miscellaneous types-sorption heat pipe (SHP), viii) magnetic fluid heat pipes, and ix) two-phase, closedthermosyphon (TPCT) or wickless heat pipes. Heat pipes that work under gravity with the condenser above the evaporator do not require external power or capillary action to return the working fluid from the condenser to the evaporator. Such heat pipes are known as thermosyphons or wickless heat pipes [6]. Condensation of the working fluid occurs due to gravity, so the evaporator must be positioned at a lower position than the condenser. Due to their simple structure, stable operating conditions, and extensive range of operating temperatures, thermosyphons are in many industrial applications [7].

TPCT heat pipes consist of three parts, i.e., the evaporator, adiabatic section, and condenser section. The evaporator section of the thermosyphon is always at the bottom so the condensate can return to 
this section by gravity flow. The operating process begins at the evaporator section, which is filled with a certain amount of working fluid. The working fluid is a saturated liquid, which is heated by a heat source, such as a hot bath or electrical heating element. Then, the saturated liquid changes to a vapor and moves up to the condenser section. After that, the vapor in the condenser section transfers the heat to a heat sink, such as cool water. As a result, the vapor condenses to a liquid and flows down to the evaporator section [8]. Figure 1 shows a schematic view of the working principle of the TPCT.

Since the first basic heat pipe concept was proposed by Gaugler [10], several investigations [9] have been conducted with the goals of enhancing the thermal performance of the thermosyphon and understanding the effects of various parameters and operating conditions on its performance. These are categorized mainly into three approaches in [11], i.e., 1) use of an efficient working fluid, 2) mechanical and surface modifications, and 3) mathematical and computational modelling.

Elmosbahi et al. [1] investigated the effect of the working fluid inventory on the performance of the gravity-assisted solar heat pipe. The results indicated that the optimum performance occurred when the evaporator's volume was two-thirds filled with methanol. There are basic parameters that influence the thermal performance of the TPCT, such as the working fluids, inclination angle, heat input, and filling ratio. Fadhl et al. [12] investigated the performance of a water-filled thermosyphon. They conducted experiments in which they studied the effects of the difference in the temperatures of the cooling water at the inlet and at the outlet, the temperature of the wall of the thermosyphon, and flowrate of the cooling water. The thermosyphon was made of a copper material, and it had an outer diameter of $22 \mathrm{~mm}$ and a wall thickness of $0.9 \mathrm{~mm}$. The overall length of thermosyphon was $500 \mathrm{~mm}$, consisting of a 200-mm evaporator, a 100-mm adiabatic section, and a 200-mm condenser. The performance of the thermosyphon was studied numerically using the volume of fluid (VOF) method that is commercially available in ANYSYS Fluent computational fluid dynamics software. The results that were obtained from the experimental and numerical studies were compared, and they indicated in their paper that there was good agreement between them.

Depending on the working conditions, different working fluids have been used in thermosyphons. Kanan et al. [7] investigated the effect of operating parameters on the heat transport capability of TPCT using water, methanol, ethanol, and acetone as the working fluids. These working fluids were 
evaluated based on some critical features, such as boiling point, their heat of evaporation, compatibility with other materials, thermal conductivity, wettability, vapor pressure, thermal stability, kinematic viscosity, coefficient of surface tension, and freezing point. A high latent heat of vaporization is desirable for a working fluid, as are high surface tension, low viscosity, and thermal stability. The most-preferred working fluids in TPCT are water [13], methanol, ammonia, and other refrigerants [14, 15]. Jouhara and Robinson [16] investigated the performance of thermosyphons charged with water as well as the dielectric heat transfer liquids, i.e., FC-84, FC-77, and FC-3283. Payakaruk et al. [17] investigated the heat transfer characteristic of a gravity-assisted, two phase, closed thermosyphon charged with R22, R123, R134a, ethanol, and water as the working fluids with varying angles of inclination. Esen and Esen [18] investigated the thermal performance of a twophase, closed thermosyphon solar collector using R-134a, R407C, and R410A refrigerants. Sundaram et al. [19] experimentally investigated a two-phase, closed thermosyphon for telecommunication shelters in tropical and desert regions. Working fluids that had low global warming potential were investigated by MacGregor et al. for a closed, two-phase thermosyphon [20]. The results of their experimental work showed that a 95/5\% water/ethylene glycol mixture was a suitable replacement fluid, although, under certain conditions, its performance was less than that of R134a.

The effect of filling ratio on the heat transfer characteristics of TPCT was investigated by Park et al. [21] and Ong and Alalhi [22]. The effect of the inclination angle on the thermal performance of a two-phase, closed thermosyphon using copper tubes with filling ratios of 15, 22, and 30\% was investigated experimentally by Noie et al. [23]. In their study, they used a copper thermosyphon with an outside diameter of $16 \mathrm{~mm}$, an inside diameter of $14.5 \mathrm{~mm}$, and a length of $1000 \mathrm{~mm}$, and they used distilled water as the working fluid. They concluded that the two-phase, closed thermosyphon had its best thermal performance at inclination angles in the range of $15^{\circ}-60^{\circ}$ and a filling ratio of $30 \%$ or greater. Emami et al. [24] experimentally studied the effects of aspect ratio and filling ratio on the thermal performance of an inclined, two-phase, closed thermosyphon. The filling ratio was varied from 20 to $60 \%$ for the working fluid, which was distilled water in their study. The best thermal performance of the inclined thermosyphon was reported for an inclination angle of $60^{\circ}$ and a filling ratio of $45 \%$. 
In recent years, many researchers [25-27] have focused on nanofluids, which are rapidly emerging as alternatives to conventional heat transfer fluids. Khandekar et al. [28] investigated the overall thermal resistance of a two-phase, closed thermosyphon using pure water and various water-based nanofluids as working fluids. Noie et al. [29] studied the efficiency of TCPT using an $\mathrm{Al}_{2} \mathrm{O}_{3} /$ water nanofluid instead of pure water. They concluded that efficiency of the TPCT charged with nanofluid was 14.7\% greater than when it was charged with water. Baojin et al. [30] experimentally investigated the heat transfer characteristics of a titanium/water and copper/water fluids in two-phase closed thermosyphon. They found that no remarkable differences of heat transfer coefficient in evaporator between $\mathrm{Ti} / \mathrm{H}_{2} \mathrm{O}$ TPCTs and $\mathrm{Cu} / \mathrm{H}_{2} \mathrm{O}$ TPCTs.

Although the research work that has been conducted on TPCT has been well documented, far less work has been conducted for thermosyphons charged with mixtures of water, ethanol, and ethylene glycol for different operation conditions, such as different inclination angles, cooling water flow rates, and heat inputs. Motivated by the studies mentioned above, the main objective of our study was to compare the thermal performance of water, ethanol, and ethylene glycol as the working fluid in a gravity-assisted, two-phase, closed thermosyphon. Thus, we conducted an experimental investigation of the TPCT, and we designed and built an experimental test rig based on the thermosyphon. Different sets of experimental results were obtained by varying the inclination angle of the thermosyphon, the flow rate of cooling water, and the heating power input for three working fluids. The effects of the pertinent parameters on the efficiency of the thermosyphon were presented in graphs and tables.

\section{Materials and Methods}

\subsection{Experimental system}

In this paper, the results of the experimental determination of the thermal performance of a two-phase, closed thermosyphon are reported. Figure 2a shows a schematic diagram of the experimental apparatus that was used in this work. Figure $2 b$ shows the locations of the thermocouples. The apparatus consisted of a two-phase, closed thermosyphon, an electrical resistor, a power supply, a wattmeter, the cooling water flow circuit, a flow meter, and the associated instrumentation. 
In the experiment, a copper thermosyphon was used that was $100 \mathrm{~cm}$ long, had an inner diameter of $18 \mathrm{~mm}$, and had an outer diameter of $19 \mathrm{~mm}$. The thermosyphon was charged with the working fluids and was tested with an evaporator length of $45 \mathrm{~cm}$ and a condenser length of $45 \mathrm{~cm}$. The working fluids filled approximately $35 \%(44.4 \mathrm{~mL})$ of the volume of the thermosyphon. This value corresponded to approximately one-third of the total volume of the thermosyphon's heat pipe. Table 1 provides some important physical properties of the working fluids used in this study.

The heat energy emitted to the evaporator section of TPCT by the electric heater was removed from the condenser by circulating cooling water. Experimantal observations were made of the temperature distribution on the surface of the TPCT, differences in the temperatures of the cooling water at the inlet and outlet of the TPCT for different heating power inputs, different inclination angles, and different flowrates of cooling water. The experiments were performed at cooling water flowrates 10 , 20 , and $30 \mathrm{~L} / \mathrm{h}$, at inclination angles of $30^{\circ}, 60^{\circ}$, and $90^{\circ}$, and heating power inputs of 200,400 , and $600 \mathrm{~W}$.

In order to observe the temperature distribution along the outer surface of the thermosyphon, nine Ktype thermocouples were used, three of which were placed on the condenser, three on the evaporator, one in the adiabatic area, one at the inlet, and one at the outlet of the cooling water. Figure $2 \mathrm{~b}$ shows the locations of the thermocouples. With a module that received the signals from the thermocouples (Adam 4018 and 4019), the temperature values were transferred to a computer and recorded. After the thermocouples were positioned, a copper pipe with a diamter of $28 \mathrm{~mm}$ and a length of $45 \mathrm{~cm}$ was welded to the condenser area of the thermosyphon, and a water jacket was formed. A volumetric flow measurement mechanism that consisted of glass spheres was used to measure the flow of water passing from the condenser. A nickel-chromium resistance coil, which had a resistance of five ohms and a power of $100 \mathrm{~W}$, was wrapped and placed on the evaporator area as an external heat source. Ceramic balls were used to prevent the wrapped resistance from coming in contact with the copper pipe, which would have short-circuited the setup. The power of the external heat input applied to the evaporator section was controlled with a dimmer circuit and measured with a $220 \mathrm{~V} / 10$ A wattmeter connected to the circuit. The external surface of the evaporator, condenser, adiabatic areas of the thermosyphon, and the water tank were insulated to minimize any heat losses. Since $100 \%$ isolation is impossible, the thermosyphon was isolated using $6 \mathrm{~cm}$ of glasswool, and the heat loss was 
calculated for each evaporator heat input (200, 400, and $600 \mathrm{~W})$ and each working fluid, and a $10 \%$ heat loss to the surroundings was determined based on the data available in the literature. This amount of heat loss was calulculated as shown in the Appendix section, and it is given in Table 2. The heat loss was considered during the calculations of the thermal resistances and efficiencies of the TPCT. Foreign substances inside the thermosyphon were removed using pure water, and then a capillary tube was attached to the top cover of the condenser area and welded in place so that vacuuming could be performed. Then, the thermosyphon was filled completely with the working fluid. The heater resistances that were placed on the evaporator area were operated until the working fluid started to leave the capillary tube, after which the end of the capillary tube was closed, and the vacuuming process was completed. After the production stage of the thermosyphon was completed, it was ready for experimental testing.

During the experiments, the time required for the thermosyphon to reach steady state was determined first in order to identify the experimental period. As a result of the experiments performed within one hour, it was seen that the thermosyphon reached steady state within approximately 20 minutes for pure water, ethanol, and ethylene glycol. Taking this period into consideration, the length of the experiments was determined to be 30 minutes. When the temperatures of the initial cooling water become steady for a given flowrate, the experiments were repeated. In the experiments, temperature measurements were recorded in five-minute intervals, and, taking into account the time the thermosyphon required to reach the steady state regime the change in surface temperatures of the thermosyphon, thermal resistance, and efficiency curves were drawn based on the results of measurements recorded in $30^{\text {th }}$ minute.

\subsection{Data Reduction and Uncertainty}

Using the data obtained from the experiments, the performance of the thermosyphon under a variety of parameters, such as working fluid, inclination angles, cooling water flowrate, and applied heating power input, was determined using the following equations:

Differences in the temperatures of the cooling water at the inlet and outlet of condenser, mass flow, and specific heat values of water were used in calculating the amount of heat transfer to the cooling fluid. 
$\dot{Q}_{c}=\dot{m}_{w} c_{p}\left(T_{w, o}-T_{w, i}\right)$

The ratio of the heat ejected from the condenser to the heat received from the evaporator was defined as the efficiency of the thermosyphon, and it was calculated with equation (2.2).

$\eta=\frac{\dot{Q}_{c}}{\dot{Q}_{e}}$

The overall thermal resistance, defined as the ratio of the temperature difference between the evaporator and condenser to the heating power input, is used extensively to evaluate the thermal performance of a thermosyphon, and a lower value of thermal resistance usually means higher thermal performance. The overall thermal resistance of a TPCT is defined as:

$R=\frac{T_{e}-T_{c}}{\dot{Q}_{e}}=\frac{\left(\frac{T_{w, e 1}+T_{w, e 2}+T_{w, e 3}}{3}\right)-\left(\frac{T_{w, c 1}+T_{w, c 2}+T_{w, c 3}}{3}\right)}{\dot{Q}_{e}}$,

where Te and Tc are the average wall temperatures of the evaporator and condenser, respectively.

In the present work, the measurement uncertainties of temperature were \pm 0.5 , which contains a measurement error of $\pm 0.05^{\circ} \mathrm{C}$ by the thermocouples.

The uncertainty in the measurement of the heating power input was $2 \%$. The error associated with the cooling water flow rate was $0.5 \%$. The uncertainties of efficiency, which were calculated by directly measured values, such as temperature, the mass flowrate of the cooling water, and heating power input, generally are denoted as $\partial_{x}$, described as follows [31,32]:

$w_{R}=\left[\left(\frac{\partial R}{\partial X_{1}} w_{1}\right)^{2}+\left(\frac{\partial R}{\partial X_{2}} w_{2}\right)^{2}+\cdots \cdots \cdots \cdots \cdots+\left(\frac{\partial R}{\partial X_{n}} w_{n}\right)^{2}\right]^{\frac{1}{2}}$,

where $\mathrm{R}$ is a given function of the independent variables $\mathrm{x} 1, \mathrm{x} 2, \mathrm{x} 3, \ldots, \mathrm{xn}$, and $w_{R}$ is the uncertainty of the results. Through calculations, the uncertainty values of efficiency were less than $5 \%$. 


\section{Results and Discussion}

The results obtained from the experiments plotted on graphs as change in the surface temperature of the thermosyphon, thermal resistance of TPCT, and change in the temperature difference of the cooling water based on the data from the temperature measurement points. These results were examined in detail.

Figure 3 shows the temperature distributions on the surface of the thermosyphon measured at 200, 400 , and $600 \mathrm{~W}$ of heating power input, $30^{\circ}, 60^{\circ}$, and $90^{\circ}$ inclination angles, and 10, 20, and $30 \mathrm{~L} / \mathrm{h}$ flowrates of cooling water with pure water being used as the working fluid. The figure shows that, in general, the heat energy extracted from the condenser area increased as the flowrate of the cooling water increased; thus, the surface temperature of condenser area decreased accordingly. For example, at $200 \mathrm{~W}$ of heating power input, a $30^{\circ}$ inclination angle, and a cooling water flowrate of $10 \mathrm{~L} / \mathrm{h}$, the average of the temperatures distributed of the condenser area became about $33{ }^{\circ} \mathrm{C}$, whereas the average was about $21{ }^{\circ} \mathrm{C}$ at a flowrate of $30 \mathrm{~L} / \mathrm{h}$. An increase in the heat energy extracted from the condenser area the working fluid to condense in a very short time, resulting in faster circulation inside the thermosyphon. For this reason, the distribution of temperatures in the evaporator area decreased cooling water flowrate increased. For example, at $200 \mathrm{~W}$ of heating power input, a $30^{\circ}$ inclination angle, and a cooling water flowrate of $10 \mathrm{~L} / \mathrm{h}$, the average of the temperatures on the evaporator area became $84.9{ }^{\circ} \mathrm{C}$, whereas the average was about $75{ }^{\circ} \mathrm{C}$ at a cooling water flowrate of $30 \mathrm{~L} / \mathrm{h}$. When the inclination angle of the thermosyphon was increased from $30^{\circ}$ to $60^{\circ}$, the temperature distribution on the evaporator area decreased from 84.9 to $81.93{ }^{\circ} \mathrm{C}$ at $200 \mathrm{~W}$ of heating power input and $10 \mathrm{~L} / \mathrm{h}$ cooling water flowrate, whereas the average temperature distribution of the condenser area increased from 32.56 to $35.5^{\circ} \mathrm{C}$. These values indicated that, in general, the amount of heat energy transferred from the evaporator area to the condenser area increases as the angle of inclination increases. A similar situation also was observed at other heating power inputs, inclination angles, and cooling water flowrates. This was because, at the vertical position, the condensate returns to the evaporator rapidly.In this study, the lower inclination angles reduced the efficiency due to the obstruction of the vapor with condensate return from the condenser to the evaporator [33]. 
Figure 4 shows the thermosyphon surface temperature distributions measured at 200, 400, and 600 $\mathrm{W}$ heating power input; $30^{\circ}, 60^{\circ}$, and $90^{\circ}$ inclination angles; and 10, 20, and $30 \mathrm{~L} / \mathrm{h}$ cooling water flowrates when ethanol was used as the working fluid. The figure shows that the surface temperature distribution on the thermosyphon became less stable when ethanol was used as the working fluid instead of water. The reason for this phenomenon was assumed to be due to the fact that ethanol has a lower evaporation temperature than water. At $200 \mathrm{~W}$ of heat input, a $30^{\circ}$ inclination angle, and 10 $\mathrm{L} / \mathrm{h}$ cooling water flowrate, the average temperature of evaporator area was $69.03{ }^{\circ} \mathrm{C}$, whereas the average value was $79.9^{\circ} \mathrm{C}$ at $30 \mathrm{~L} / \mathrm{h}$ water flowrate. When the inclination angle was $90^{\circ}$ at the same heat input, the average temperatures of the evaporator area were 61.03 and $56 .{ }^{\circ} \mathrm{C}$ at 10 and $30 \mathrm{~L} / \mathrm{h}$ cooling water flowrates, respectively. Although evaporator area surface temperature distribution was lower compared to water, as water is being used, the cooling water flowrate increased and surface temperature decreased, but just the opposite occurred when ethanol was used. The average temperature of the condenser area was $29.8^{\circ} \mathrm{C}$ at $200 \mathrm{~W}$ of heat input, a $30^{\circ}$ inclination angle, and $10 \mathrm{~L} / \mathrm{h}$ cooling water flowrate, but it was found to be $22.6^{\circ} \mathrm{C}$ at $30 \mathrm{~L} / \mathrm{h}$ water flowrate. The average temperatures of the condenser area at the same values were 36.1 and $31.2{ }^{\circ} \mathrm{C}$ at the $90^{\circ}$ inclination angle. These values were close to the values measured for water. According to these values, the heat energy transferred to the condenser area for ethanol was similar to the situation with water as the inclination angle of the thermosyphon increased.

Figure 5 shows the thermosyphon surface temperature distributions measured at 200, 400, and 600 $\mathrm{W}$ heating power input; $30^{\circ}, 60^{\circ}$, and $90^{\circ}$ inclination angles; and 10, 20 and $30 \mathrm{~L} / \mathrm{h}$ cooling water flowrates when ethylene glycol was used as the working fluid. The figure showsw that the temperature distribution of evaporator area became $86.3^{\circ} \mathrm{C}$ at $200 \mathrm{~W}$ heat input, $30^{\circ}$ inclination angle and $10 \mathrm{~L} / \mathrm{h}$ cooling water flowrate, whereas the temeperature distribution was $84.16{ }^{\circ} \mathrm{C}$ at $30 \mathrm{~L} / \mathrm{h}$ water flowrate. The evaporator area temperature distribution at the same values at $90^{\circ}$ inclination angle was observed as 89.43 and $86.56{ }^{\circ} \mathrm{C}$. It was found to be higher than for water and ethanol, and, as was the case with water, the surface temperature decreased as the cooling water flowrate increased. The temperature distribution of the condenser area became $34.3^{\circ} \mathrm{C}$ on average at $200 \mathrm{~W}$ heat input, $30^{\circ}$ inclination angle, and $10 \mathrm{~L} / \mathrm{h}$ cooling water flowrate, and, for $30 \mathrm{~L} / \mathrm{h}$ water flowrate, it was $30.4{ }^{\circ} \mathrm{C}$. The condenser area temperature distribution at the same values at $90^{\circ}$ inclination angle were observed to be 33.10 and $27.63^{\circ} \mathrm{C}$. According to these measured values, it was observed that the heat energy 
transferred to the condenser area increased in ethylene glycol just like in water and ethanol as the inclination angle of the thermosyphon increased. When the figures showing thermosyphon surface temperatures for water, ethanol, and ethylene glycol are compared, it can be seen that, when ethylene glycol is used as the working fluid, a more stable temperature distribution was obtained. It is estimated that this was because ethylene glycol is a good heat transfer fluid.

At $200 \mathrm{~W}$ of heat input, the average temperature of the evaporator's surface area at all flowrates and inclination angles was $80.81{ }^{\circ} \mathrm{C}$, whereas this value was $86.27{ }^{\circ} \mathrm{C}$ for ethylene glycol. When the heat input was $600 \mathrm{~W}$, these values were observed to be $113.81{ }^{\circ} \mathrm{C}$ for pure water and $131.89{ }^{\circ} \mathrm{C}$ for ethylene glycol. At $200 \mathrm{~W}$ of heat input, the average temperature on the surface of the condenser was $29.5{ }^{\circ} \mathrm{C}$ for water and $31.1^{\circ} \mathrm{C}$ for ethylene glycol. At $600 \mathrm{~W}$ of heat input these values became 39.2 ${ }^{\circ} \mathrm{C}$ for water and about $41.4{ }^{\circ} \mathrm{C}$ for ethylene glycol. When these values were taken into account, it was observed that the average temperatures of the surface areas of the evaporator and the condenser were greater for the same heat input when ethylene glycol was used as the working fluid instead of water.

Figure 6 shows the overall thermal resistance of the TPCT for different working fluids at a constant inclination angle $\left(90^{\circ}\right)$ and various flowrates as a function of heating power input. The figure clearly shows that, for all three working fluids, the overall thermal resistance of TPCT decreased as the heat input increased and that it increased as the flowrate of the cooling water increased. Similar tends were observed in previous published studies $[34,35]$.

When water was working fluid, thermal resistance was measured as $0.254,0.263$, and $0.282{ }^{\circ} \mathrm{C} / \mathrm{W}$ for cooling water flowrates of 10, 20, and $30 \mathrm{~L} / \mathrm{h}$, respectively, at the $200 \mathrm{~W}$ heat input. The thermal resistance decreased as heating power input increased. The lowest values of thermal resistance at the cooling water flowrates of 10,20 , and $30 \mathrm{~L} / \mathrm{h}$ were $0.125,0.135$, and $0.140{ }^{\circ} \mathrm{C} / \mathrm{W}$, respectively. Similar situations also were obsreved for other fluids. At the $90^{\circ}$ inclination angle, the lowest value of thermal resistance occured when using ethanol, and the highest value occurred when using ethylene glycol. The differences in the thermal resistances at the different flow rates were small at the lower heat inputs for ethylene glycol, but they were high for water and ethanol. As the heat input increased, $\mathrm{t}$ was clear that the differences in the thermal resistance increased when ethanol was used. 
Figure 7 shows the differences in the values of the inlet and outlet temperatures for the cooling water measured at three different flowrates with heat inputs of 200, 400, and $600 \mathrm{~W}$ and inclination angles of $30^{\circ}, 60^{\circ}$, and $90^{\circ}$ for water, ethanol, and ethylene glycol, respectively, as working fluids. As the inclination angle of the thermosyphon increased, the impact of the force of gravity increased, and, in turn, the measured differences in the inlet and outlet temperatures of the cooling water also increased. When a heat input of $200 \mathrm{~W}$ was applied to the evaporator area with water as the working fluid, the average temperature difference was $13.2^{\circ} \mathrm{C}$ at a water flowrate of $10 \mathrm{~L} / \mathrm{h}$ and an inclination angle of $30^{\circ}$. The averages of the temperature differences were 13.9 and $16.2^{\circ} \mathrm{C}$ for $60^{\circ}$ and $90^{\circ}$ inclination angles, respectively. These values for ethanol were 9.6, 11.1, and $13.1{ }^{\circ} \mathrm{C}$, and, for ethylene glycol, they were $11.7,12.5$, and $14.5^{\circ} \mathrm{C}$. When the same heat input (200 W) at cooling water flowrate was $30 \mathrm{~L} / \mathrm{h}$, the temperature differences were measured as 3.4, 4.0, and $5.0{ }^{\circ} \mathrm{C}$ for inclination angles of $30^{\circ}, 60^{\circ}$, and $90^{\circ}$, respectively. At the same values of inclination angle, the temperature differences 4.1, 4.7, and $5.3{ }^{\circ} \mathrm{C}$ for ethanol and $4.9,5.3$, and $5.55^{\circ} \mathrm{C}$ for ethylene glycol.

When a heat input of $600 \mathrm{~W}$ was applied to the evaporator area with water as the working fluid, the temperature difference at a flowrate of $10 \mathrm{~L} / \mathrm{h}$ and an inclination angle of $30^{\circ}$ was $15.2^{\circ} \mathrm{C}$, and it was 16.8 and $18.7^{\circ} \mathrm{C}$ for inclination angles of $60^{\circ}$ and $90^{\circ}$, respectively. Temperature difference values for ethanol at the same values $\left(600 \mathrm{~W}\right.$ heat input, $10 \mathrm{~L} / \mathrm{h}$ cooling water flowrate and $30^{\circ}, 60^{\circ}$ and $90^{\circ}$ inclination angle), was measured as $25.4,28.2$, and $30^{\circ} \mathrm{C}$, and they were $15.8,17.5$, and $19.1{ }^{\circ} \mathrm{C}$ for ethylene glycol. When the same heat input $(600 \mathrm{~W})$ at cooling water flowrate was $30 \mathrm{~L} / \mathrm{h}$, the temperature differences were 5.05, 6.8, and $8.9^{\circ} \mathrm{C}$ for inclination angles of $30^{\circ}, 60^{\circ}$, and $90^{\circ}$, respectively for water as the working fluid. At the same values $(600 \mathrm{~W}$ heat input, $30 \mathrm{~L} / \mathrm{h}$ cooling water flowrate and $30^{\circ}, 60^{\circ}$ and $90^{\circ}$ inclination angle), the temperature differences for ethanol were $7.4,8.2$, and $10.5^{\circ} \mathrm{C}$, and, for ethylene glycol, they were 8.0, 8.3, and $8.9^{\circ} \mathrm{C}$. Figure 7 shows that increasing the inclination angle of the thermosyphon has led to raise cooling water temperature difference values. Likewise, an increase in the heating power input applied to evaporator area increased the temperature difference values of the fluids at the same flowrates. Increasing the flowrate resulted in decreasing the values of the temperature differences for all three working fluids [35].

Figure 8 shows the thermal performance of TPCT at different values of heat input, cooling water flowrates, and inclination angles. The graphs show that increasing the heating power input decreased 
the efficiency. For example, at a heating power input of $200 \mathrm{~W}$ and a cooling water flowrate of 10 $\mathrm{L} / \mathrm{h}$ with water as the working fluid, the efficiency was $76 \%$ at an inclination angle of $30^{\circ}$, but it was 80.6 and $93.8 \%$ for inclination angles of $60^{\circ}$ and $90^{\circ}$, respectively. At the same values of heat input and cooling water flowrate, ethanol and ethylene glycol as working fluids showed similar characteristics; their efficiency values for the $30^{\circ}$ inclination angle were 55.6 and $67.8 \%$, respectively, but they became $64.3 \%$ and $75.9 \%, 72.4 \%$ and $84 \%$ for 60 and $90^{\circ}$ inclination angles respectively. When heat input was increased from 200 to $600 \mathrm{~W}$, the efficiency values for water, ethanol, and ethylene glycol as working fluids were decreased by 61,25 , and 56\%, respectively. At low heat input, water is more efficient, whereas ethanol is more efficient at high heat input. At the same heat input, an increase in the flowrate of the cooling water decreased some efficiency values and increased others. For example, the efficiency was $93.8 \%$ for water as the working fluid, a $200 \mathrm{~W}$ heat input, an inclination angle of $90^{\circ}$, and a cooling water flowrate of $10 \mathrm{~L} / \mathrm{h}$, but it decreased to $87.1 \%$ at a cooling water flowrate of $30 \mathrm{~L} / \mathrm{h}$. However, when ethanol was the working fluid, for identical values of heat input $(200 \mathrm{~W})$ and the inclination angle $\left(90^{\circ}\right)$, the efficiency was $75.9 \%$ at a flow rate of $10 \mathrm{~L} / \mathrm{h}$, and it was $92.4 \%$ at a flow rate of $30 \mathrm{~L} / \mathrm{h}$. Ethylene glycol showed similar characteristics, with its efficiency increasing from 84 to $96.7 \%$ when the flowrate was increased from 10 to $30 \mathrm{~L} / \mathrm{h}$, respectively. The same situation also was observed for the other heat input, and this is clearly explained by equation (2.1), which indicates that a $100 \%$ increase in the flowrate sometimes results in temperature differences that are up to $100 \%$ higher (Figure 7) and that the efficiency values tended to increase or decrease depending on the flowrate. Other studies in the literature have documented this phenomenon. Karthikeyan et al. [36] found that the efficiency values increased with flowrate, but Sözen et al. [35] indicated that efficiency values decreased as the flowrate increased. The results of the present study were compared with some results published in the literature, taking into consideration of the inclination angle, mass flow rate, heating power input, thermal resistance, and efficiency for water as the working fluid. These comparisons are given in Table 3, which shows that there was good agreement.

\section{Conclusions}

An experimental study was conducted to investigate the thermal performance of a two-phase, closed thermosyphon considering different operating conditions, i.e., i) heating power input, ii) inclination 
angle, iii) cooling water flowrate, and iv) working fluids. An experimental test rig was designed and built. After a series of experimental tests, the temperature of the surface of the wall of the TPCT and the inlet and outlet temperatures of the cooling water were determined. The data that were obtained from the experimental measurements were presented in graphs and discussed in detail with respect to thermal resistance, temperature differences of the cooling water, and the efficiency of TPCT. Based on the analysis of the experimental results presented in this paper, the conclusions are as follows:

$\checkmark$ For the operating heat input of $200 \mathrm{~W}$ and the $10 \mathrm{~L} / \mathrm{h}$ cooling water flowrate, the water attained the highest maximum heat transport capability among the three working fluids that were tested. But at $200 \mathrm{~W}$ heat input and a cooling water flowrate of $30 \mathrm{~L} / \mathrm{h}$, ethylene glycol appeared to be a better working fluid. For $600 \mathrm{~W}$ heat input and a cooling water flowrate of $10 \mathrm{~L} / \mathrm{h}$, ethanol was the best working fluid.

When the TPCT's inclination angle was $90^{\circ}$, it was observed that the temperature difference of the cooling water that extracted heat from the condenser area and the amount of heat transferred heat were greater than for other inclination angles. In the case of the thermosyphon, the heat transfer rate increased as the inclination angle increased. Similar trends have been observed by other researchers [25,33].

At TPCT applications from sources that have low amounts of waste heat, at low cooling water flowrates, water was more effective in terms of the thermal performance of TPCT, but at higher flowrates, ethylene glycol was a more effective working fluid.

$\checkmark$ It was concluded that heat recovery from sources that have high amounts of weaste heat was more effective when ethanol was used as the working fluid rather than water or ethylene glycol. 


\section{Acknowledgements}

The author would like to thank Prof. Dr. Hüseyin Kurt, Department of Mechanical Engineering, Karabük University for his encouragement and support. I sincerely thank the anonymous reviewer for the constructive comments which are helpful for the paper revision.

\section{References}

1. Elmosbahi, MS., Dahmouni, AW, Kerkeni, C., Guizani, AA, Nasrallah, S.B. An experimental investigation on the gravity assisted solar heat pipe under the climatic conditions of Tunisia, Energy Conversion and Management 64 (2012) 594-605.

2. Jafari, D., Franco, A. Filippeschi, S. Marco, P.D. Two-phase closed thermosyphons: A review of studies and solar applications, Renewable and Sustainable Energy Reviews 53 (2016) 575593.

3. Jouhara H., Merchant H. Experimental investigation of a thermosyphon based heat exchanger used in energy efficient air handling units, Energy 39 (2012) 82-89.

4. David Reay, Ryan McGlen, Peter Kew, (2013), "Heat Pipes, 6th Edition, Theory, Design and Applications."

5. Srimuang W, Amatachaya P. A review of the applications of heat pipe heat exchangers for heat recovery. Renewable and Sustainable Energy Reviews 16 (2012) 4303-4315.

6. Lu L., Liu Z. H., Xiao H. S. Thermal performance of an open thermosyphon using nanofluids for high-temperature evacuated tubular solar collectors Part 1: Indoor experiment, Solar Energy 85 (2011) 379-387.

7. Kannan, M. Senthil, R. Baskaran R. Deepanraj, B. An experimental study on heat transport capability of a two phase thermosyphon charged with different working fluids, American Journal of Applied Sciences 11 (4): (2014) 584-591. 
8. Amatachaya P, Srimuang W. Comparative heat transfer characteristics of a flat two-phase closed thermosyphon (FTPCT) and a conventional two-phase closed thermosyphon (CTPCT). International Communication in Heat and Mass Transfer, 37 (2010) 293-298.

9. Khazaee, I., Experimental investigation and comparison of heat transfer coefficient of a two phase closed thermosyphon, International Journal of Energy and Environment, 5 4: (2014) 495-504.

10. Gaugler RS. Heat transfer device, U.S. Patent No. 2,350,348; 1944.

11. Aniket D.P. Ravindra Y.B. Factors Affecting the Thermal Performance of Two Phase Closed Thermosyphon: A Review, International Journal of Emerging Technology and Advanced Engineering, 2 9: (2012) 202-206.

12. Fadhl B., Wrobel, L.C., Jouhara, H. "Numerical modelling of the temperature distribution in a two-phase closed thermosyphon, Applied Thermal Engineering 60 (2013) 122-131.

13. Mahmood SL, Akhanda AR. Experimental study on the performance limitation of micro heat pipes of non-circular cross-sections. Thermal Science, 12 (2008) 91-102.

14. Ziyan HAA, Helali A, Fatouh M, Abo El-Nasr MM. Performance of a stationary and vibrated thermosyphon working with water and R-134a. Applied Thermal Engineering 21 (2001) 813830.

15. Nithyanandam, K., Pitchumani R. Computational studies on a latent thermal energy storage system with integral heat pipes for concentrating solar power, Applied Energy 103 (2013) 400-415.

16. Jouhara, H., Robinson, A.J. Experimental investigation of small diameter two-phase closed thermosyphons charged with water, FC-84, FC-77 and FC-3283, Applied Thermal Engineering 30 (2010) 201-211. 
17. Payakaruk T, Terdtoon P, Ritthidech S. Correlations to predict heat transfer characteristics of an inclined closed two-phase thermosyphon at normal operating conditions. Applied Thermal Engineering 20 (2000) 781-790.

18. Esen, M., Esen, H., Experimental investigation of a two-phase closed thermosyphon solar water heater, Solar Energy 79 5: (2005) 459-468.

19. Sundaram, A.S, Seeniraj, R.V. Velraj, R., An experimental investigation on passive cooling system comprising phase change material and two-phase closed thermosyphon for telecom shelters in tropical and desert regions, Energy and Buildings 42 (2010) 1726-1735.

20. MacGregor R.W. Kewc, P.A. Reay D.A., Investigation of low Global Warming Potential working fluids for a closed two-phase thermosyphon, Applied Thermal Engineering 51 (2013) 917-925.

21. Park, YJ. Kang, HK. Kim, CJ. Heat transfer characteristics of a two phase closed thermosyphon to fill charge ratio, International Journal of Heat and Mass Transfer 45 (2002) 4655-4661.

22. Ong, KS. Haider, MD, Alalhi, E. Experimental investigation on hysteresis effect in vertical two phase closed thermosyphons, Applied Thermal Engineering 19 (1999) 399-408.

23. Noie, SH Emamib MRS. Khoshnoodib M. Effect of Inclination Angle and Filling Ratio on Thermal Performance of a Two-Phase Closed Thermosyphon under Normal Operating Conditions, Heat Transfer Engineering 28 (4): (2007) 365-371.

24. Emami, M.R.S., Noie S.H. Khoshnoodi, M., Effect of aspect ratio and filling ratio on thermal performance of an inclined two-phase closed thermosyphon, Iranian Journal of Science \& Technology, Transaction B, Engineering, 32 (2008) 39-51.

25. Huminic, G., Huminic A., Morjan I., Dumitrache, F. Experimental study of the thermal performance of thermosyphon heat pipe using iron oxide nanoparticles, International Journal of Heat and Mass Transfer 54 (2011) 656-661. 
26. Sarafraz M.M., Hormozi F. Experimental study on the thermal performance and efficiency of a copper made thermosyphon heat pipe charged with alumina-glycol based nanofluids, Powder Technology 266 (2014) 378-387.

27. Sarafraz M.M. Hormozi, F., Peyghambarzadeh, S.M. Thermal performance and efficiency of a thermosyphon heat pipe working with a biologically ecofriendly nanofluid, International Communications in Heat and Mass Transfer 57 (2014) 297-303.

28. Khandekar S, Joshi Y.M., Mehta, B., Thermal performance of closed two-phase thermosyphon using nanofluids, International Journal of Thermal Sciences 47 (2008) 659667.

29. Noie, S.H. Heris S.Z., Kahani, M., Nowee, S.M. Heat transfer enhancement using A12O3/water nanofluid in a two-phase closed thermosyphon, International Journal of Heat and Fluid Flow 30 (2009) 700-705.

30. Baojin, Q., Li Z., Hong, X., Yan, S., Heat transfer characteristics of titanium/water two-phase closed thermosiphon, Energy Conversion and Management 50 (2009) 2174-2179.

31. Diao Y, Zhang J, Yu W, Zhao Y. Experimental study on the heat recovery characteristic of a plate heat pipe heat exchanger in room ventilation, HVAC\&R Research 20 (2014) 828-835.

32. Özgen F, Esen M, Esen H. Experimental investigation of thermal performance of a doubleflow solar air heater having aluminium cans. Renewable Energy 34 (2009) 2391-2398.

33. Chauhan, S.B., Basavaraj, M., Walke, P., Experimental Investigation of Heat Transfer Enhancement Techniques in Two Phase Closed Thermosyphon, International Journal of Engineering Research and General Science, 4 2: (2016) 97-106.

34. Solomon, A.B., Roshan, R., Vincent, W., Karthikeyan, V.K., Asirvatham, L.G., Heat transfer performance of an anodized two-phase closed thermosyphon with refrigerant as working fluid, International Journal of Heat and Mass Transfer 82 (2015) 521-529. 
35. Sözen, A., Menlik, T., Gürü, M., Boran, K., Kılıç, F., Aktaş, M., Çakıı, M.T., A comparative investigation on the effect of fly-ash and alumina nanofluids on the thermal performance of two-phase closed thermo-syphon heat pipes, Applied Thermal Engineering 96 (2016) 330337.

36. Karthikeyan, M., Vaidyanathan, S., Sivaraman, B., Thermal performance of a two phase closed thermosyphon using aqueous solution, International Journal of Engineering Science and Technology, 2 (5): (2010) 913-918.

37. Amiri, A., Sadri, R., Shanbedi, M., Ahmadi, G., Chew B.T. Kazi, S.N., Dahari, M., Performance dependence of thermosyphon on the functionalization approaches: An experimental study on thermo-physical properties of graphene nanoplatelet-based water nanofluids, Energy Conversion and Management 92 (2015) 322-330.

38. Sözen, A. Menlik, T. Gürü, M. Irmak, A. F., Kılıç F., Aktaş M. Utilization of Fly Ash Nanofluids in Two-phase Closed Thermosyphon for Enhancing Heat Transfer, Experimental Heat Transfer, 29 (2016) 337-354.

\section{Appendix}

Generally, a thermosyphon heat pipe is a pipe as follows (cross-sectional view):

What was intended to go with " 2 ?"

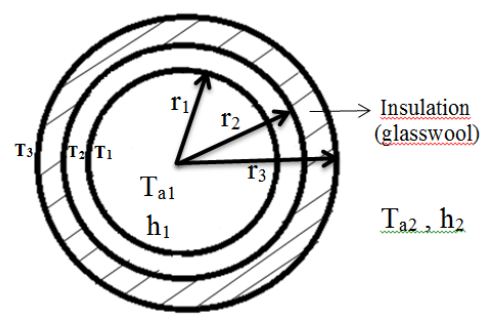

Prior to calculating heat transfer in a pipe, the heat convection coefficient of the working fluid must be determined. In this study, the velocity of the fluid in the heat pipe was $4 \mathrm{~m} / \mathrm{s}$. The inner and outer diameters of the heat pipe were 18 and $19 \mathrm{~mm}$, respectively. Accordingly:

$R e=\frac{v \cdot D_{i n}}{\vartheta}=\frac{4 \mathrm{~m} / \mathrm{s} * 0.018 \mathrm{~m}}{1.002 * 10^{-3} \mathrm{~m}^{2} / \mathrm{s}}=71.85$

As shown, $\operatorname{Re}<2300$, so the flow was laminar. For laminar flow, fully-developed flow, and constant heat flux, the Nusselt number is 4.36 (according to empirical studies). Therefore, 
$N u=\frac{h_{\text {water }} * D_{\text {in }}}{k_{\text {water }}}$

$4.36=\frac{h_{\text {water }} * 0.018}{0.607}$

$h_{\text {water }}=147.02 \mathrm{~W} / \mathrm{m}^{2} \mathrm{~K}$

Thermal resistance in this thermosyphon (without insulation):

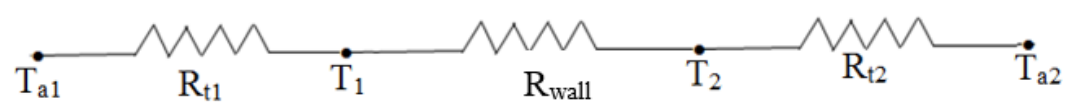

In this diagram, the subscripts $1, \mathrm{a}_{1}$ and $2, \mathrm{a}_{2}$ represent water and air, respectively. Thermal resistances are expressed as follows:

$R_{t 1}=\frac{1}{2 \pi r_{1} L h_{1}}=\frac{1}{2 \pi * 0,009 * 0,55 * 147,02}=0.218 \mathrm{~K} / \mathrm{W}$

$R_{p}=\frac{1}{2 \pi L k_{\text {wall }}} \ln \frac{D_{2}}{D_{1}}=\frac{1}{2 \pi * 0.55 * 386} \ln \frac{19}{18}=0.0000405 \mathrm{~K} / \mathrm{W}$

$R_{t 2}=\frac{1}{2 \pi r_{2} L h_{2}}=\frac{1}{2 \pi * 0.0095 * 0.55 * 20}=1.523 \mathrm{~K} / \mathrm{W}$

$Q=\frac{T_{a 1}-T_{a 2}}{R_{t 1}+R_{\text {wall }}+R_{t 2}}=\frac{T_{a 1}-25}{0.218+0.0000405+1.523}$

$* T_{a 1}$ temperature will be determined according to varying heater power $(200,400$ and $600 \mathrm{~W})$

The thickness of insulation required to decrease the heat loss at the rate of $95 \%$ is:

$Q_{\text {ins. }}=(1-0.95) * Q$

Assuming $T_{a 1}=80^{\circ} \mathrm{C}\left(80^{\circ} \mathrm{C}\right.$ corresponds to the temperature value given by the $200-\mathrm{W}$ heater.)

$Q=31.59 W$ (heat loss without being insulated)

$Q_{\text {ins. }}=0.05 * 31.59=1.58 \mathrm{~W}$ (Insulation thickness was calculated for the $1,58 \mathrm{~W}$ heat loss. This value is high, the insulation thickness was applied as $8 \mathrm{~cm}$ accordingly calculated heat loss to the environment. Calculated heat loads are given in Table 2).

The temperature decrease in the pipe:

$\Delta T_{p}=Q_{\text {ins. }} * R_{\text {wall }}=1.58 * 0.0000405=0.000064{ }^{\circ} \mathrm{C} \quad$ (Temperature difference between the pipe's interior and exterior surfaces)

Thermal resistance in this thermosyphon (with insulation): 


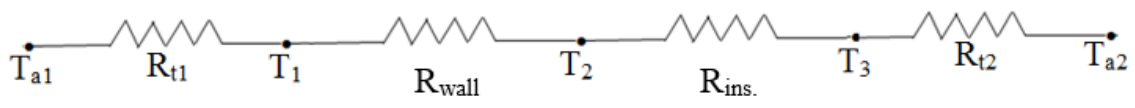

In addition to other thermal resistances, there is an $R_{\text {ins }}$ thermal resistance, which is calculated as follows:

$R_{\text {ins }}=\frac{1}{2 \pi L k_{\text {ins }}} \ln \frac{r_{3}}{r_{2}}=\frac{1}{2 \pi * 0.55 * 0.038} \ln \frac{r_{3}}{0.0095}$ and $R_{t 2}=\frac{1}{2 \pi r_{3} L h_{2}}$

In this case, the new heat transfer equation is:

$$
Q_{\text {ins. }}=\frac{T_{a 1}-25}{0.218+0.0000405+\frac{1}{2 \pi r_{3} L h_{2}}+\frac{1}{2 \pi L k_{\text {ins }}} \ln \frac{r_{3}}{r_{2}}}=1.58 \mathrm{~W}
$$

For $200 \mathrm{~W}$ heating power input:

$\frac{55}{0.218+0.0000405+\frac{1}{2 \pi r_{3} L h_{2}}+\frac{1}{2 \pi L k_{\text {ins }}} \ln \frac{r_{3}}{r_{2}}}=1.58 \mathrm{~W}$

As indicated by the last equation, this is a transcendental equation. Therefore, it only can be solved by using the trial-and-error method. The calculations of the heat losses were repeated for ethanol and ethlene glycol as working fluids, and they are given in Table 2. 


\section{FIGURE CAPTION}

Figure.1 Schematic view of the working principle of the TPCT.

Figure.2 a) Schematic diagram of the experimental apparatus b) locations of the thermocouples.

Figure.3 Temperature distributions on the surface of the thermosyphon for working fluid water with different heat input and inclination angle.

Figure.4 Temperature distributions on the surface of the thermosyphon for working fluid ethanol with different heat input and inclination angle.

Figure.5 Temperature distributions on the surface of the thermosyphon for working fluid ethylene glycol with different heat input and inclination angle.

Figure.6 Variation of heat pipe overall thermal resistance as a function of heating power input for water, methanol and ethylene glycol.

Figure.7 The inlet and outlet cooling water temperature differences $(\Delta \mathrm{T})$ in condenser section.

Figure.8 Efficiency of TPCT 


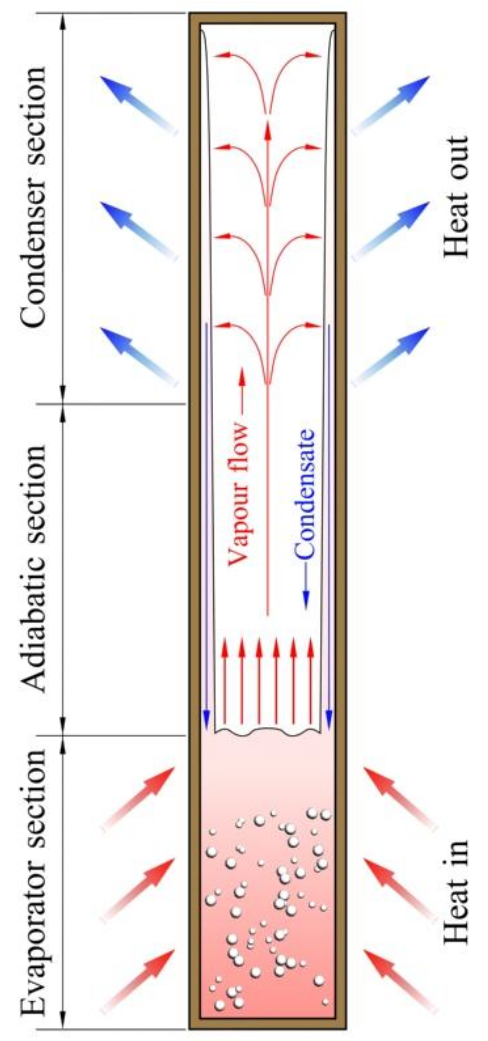

Figure 1. Schematic view of the working principle of the TPCT. 
(a)

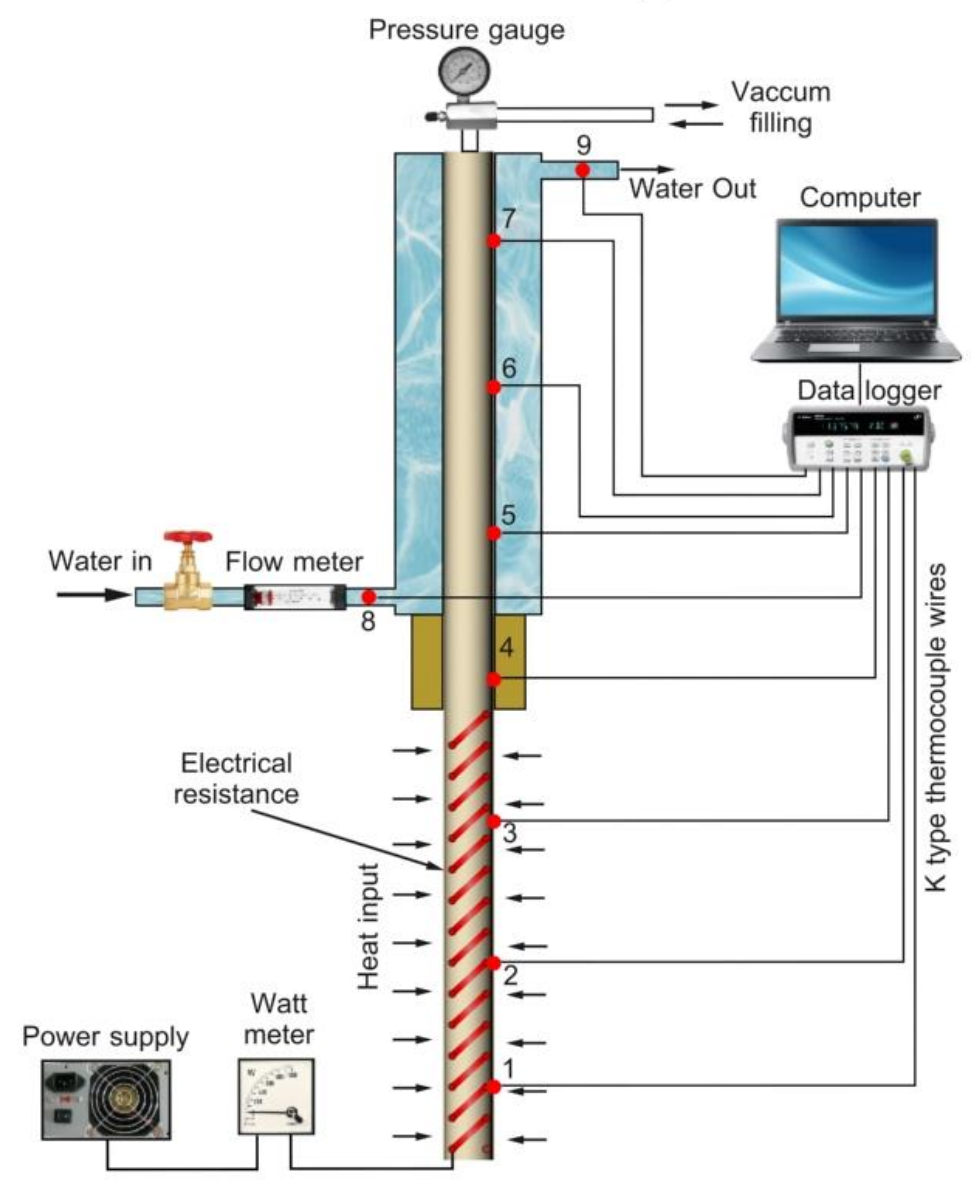

(b)

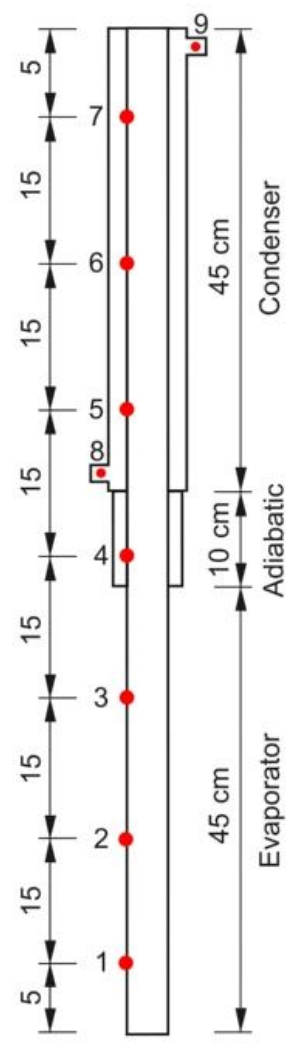

Figure 2. a) Schematic diagram of the experimental apparatus b) locations of the thermocouples. 


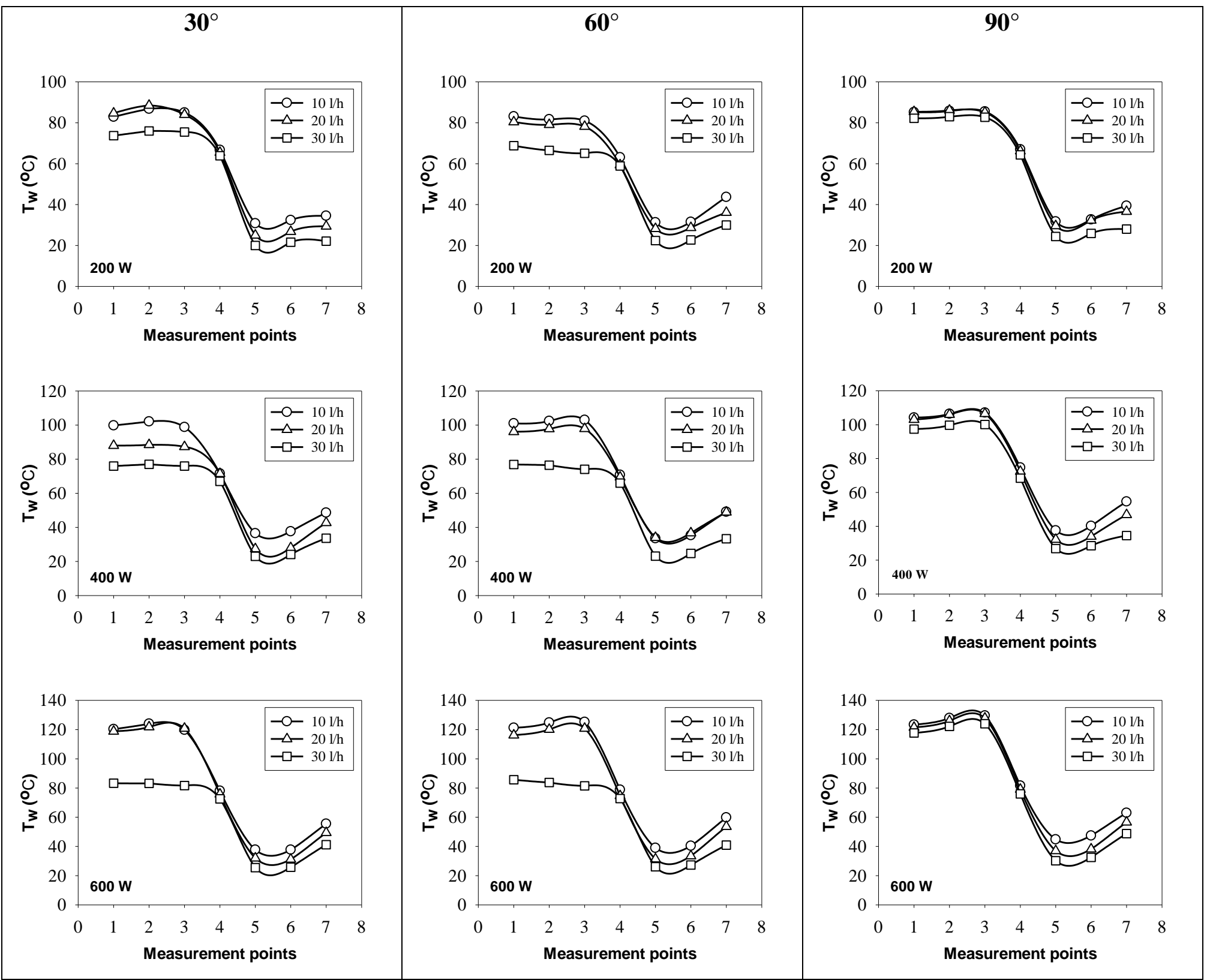

Figure 3. Temperature distributions on the surface of the thermosyphon for working fluid water with different heat input and inclination angle. 


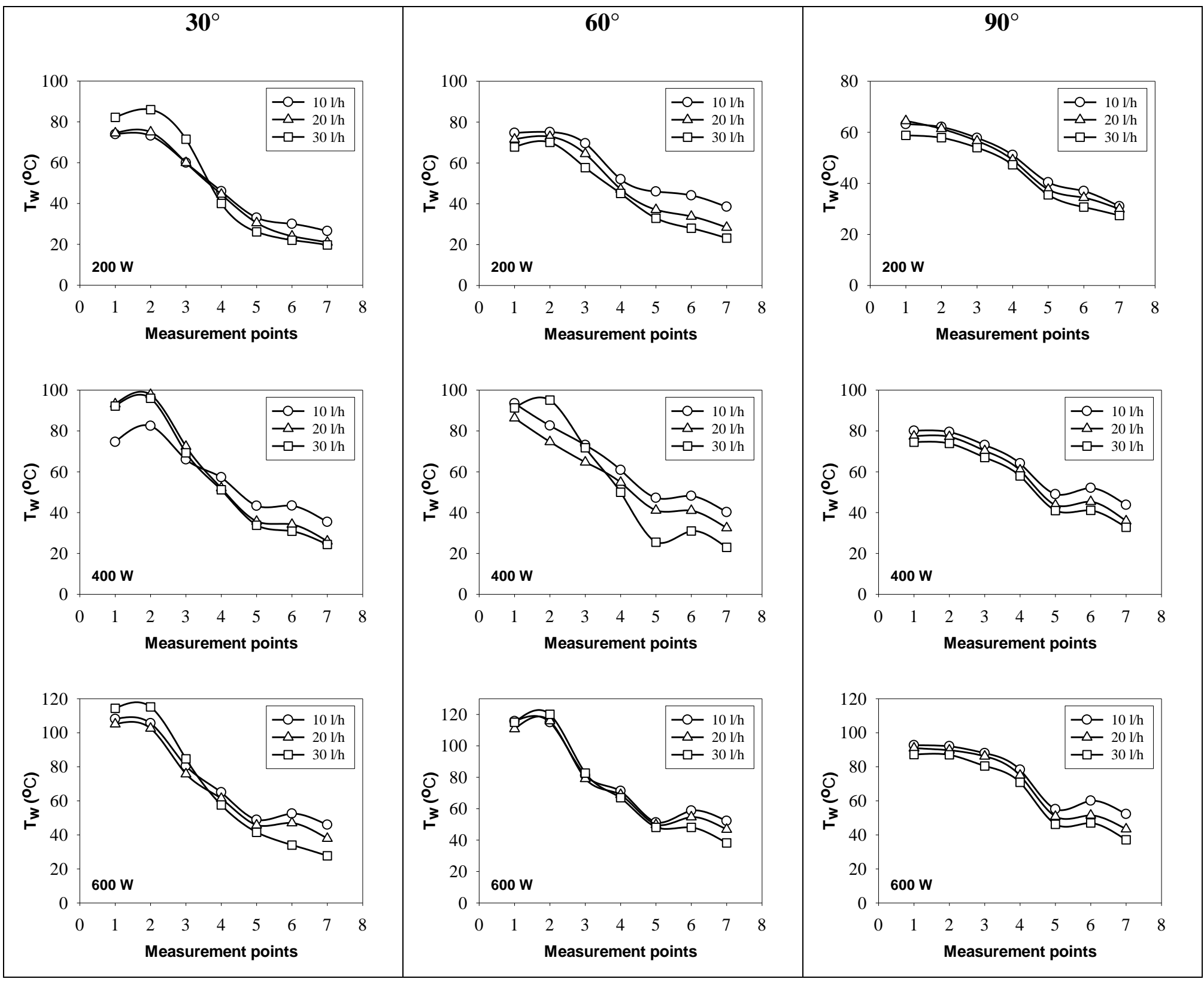


Figure 4. Temperature distributions on the surface of the thermosyphon for working fluid ethanol with different heat input and inclination angle.
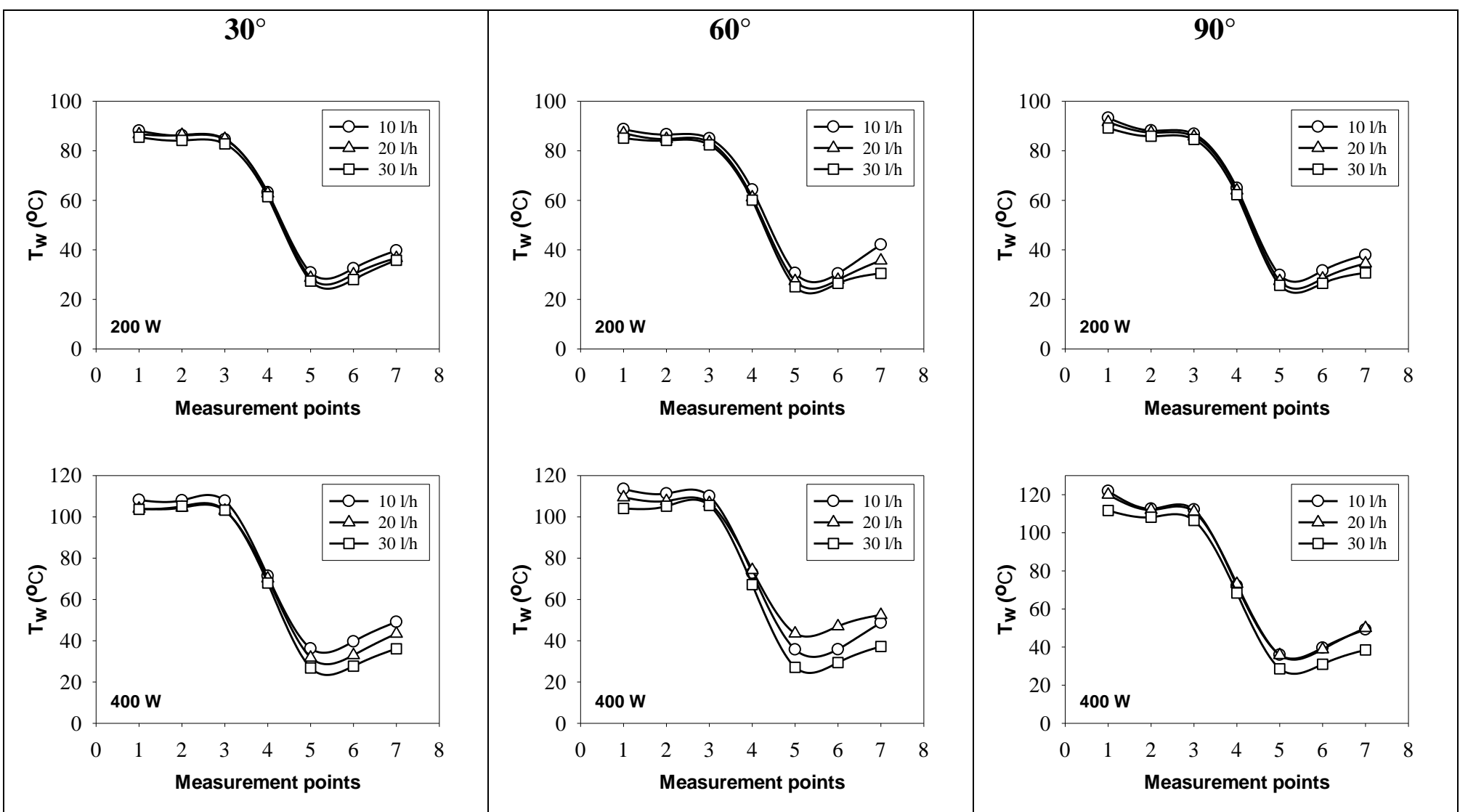


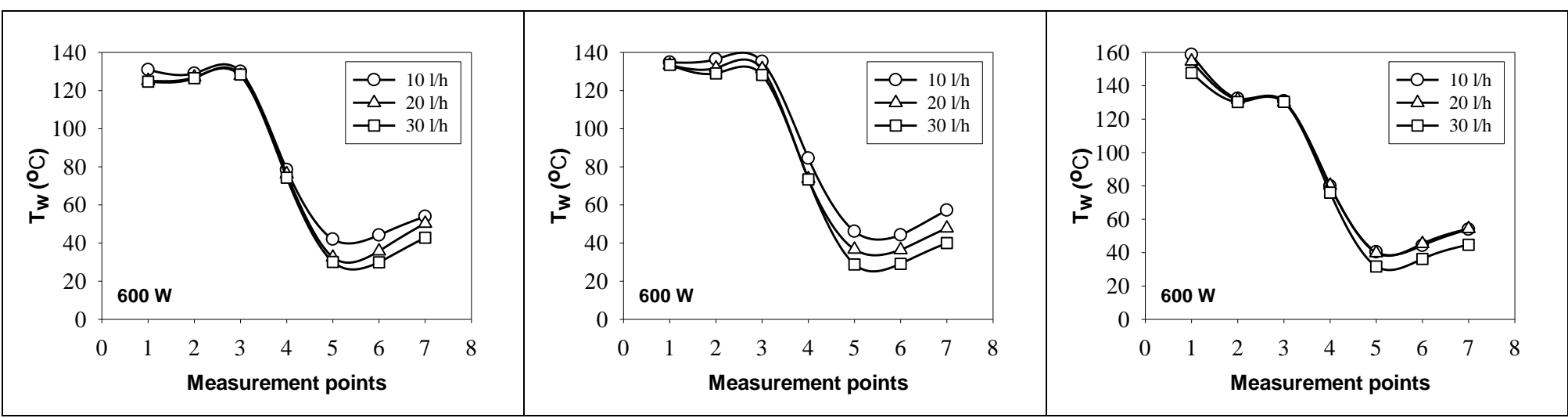

Figure 5. Temperature distributions on the surface of the thermosyphon for working fluid ethylene glycol with different heat input and inclination angle. 

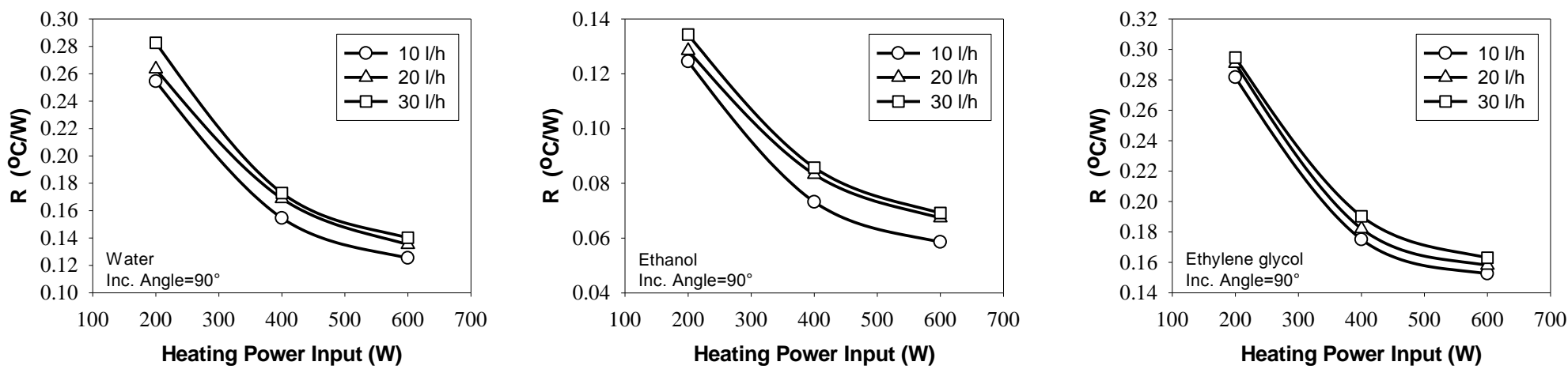

Figure 6. Variation of heat pipe overall thermal resistance as a function of heating power input for water, methanol and ethylene glycol. 


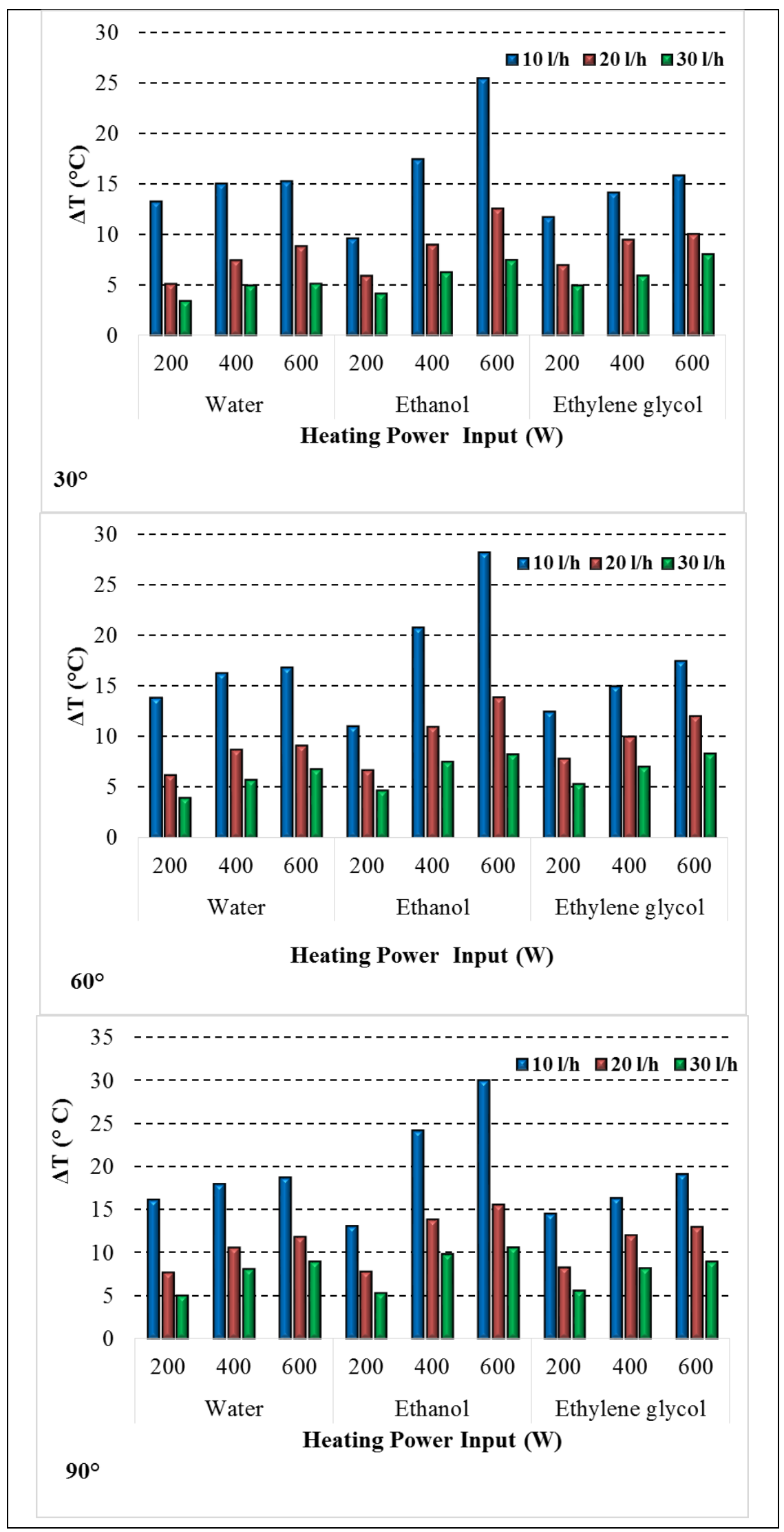


Figure 7. The inlet and outlet cooling water temperature differences $(\Delta T)$ in condenser section.
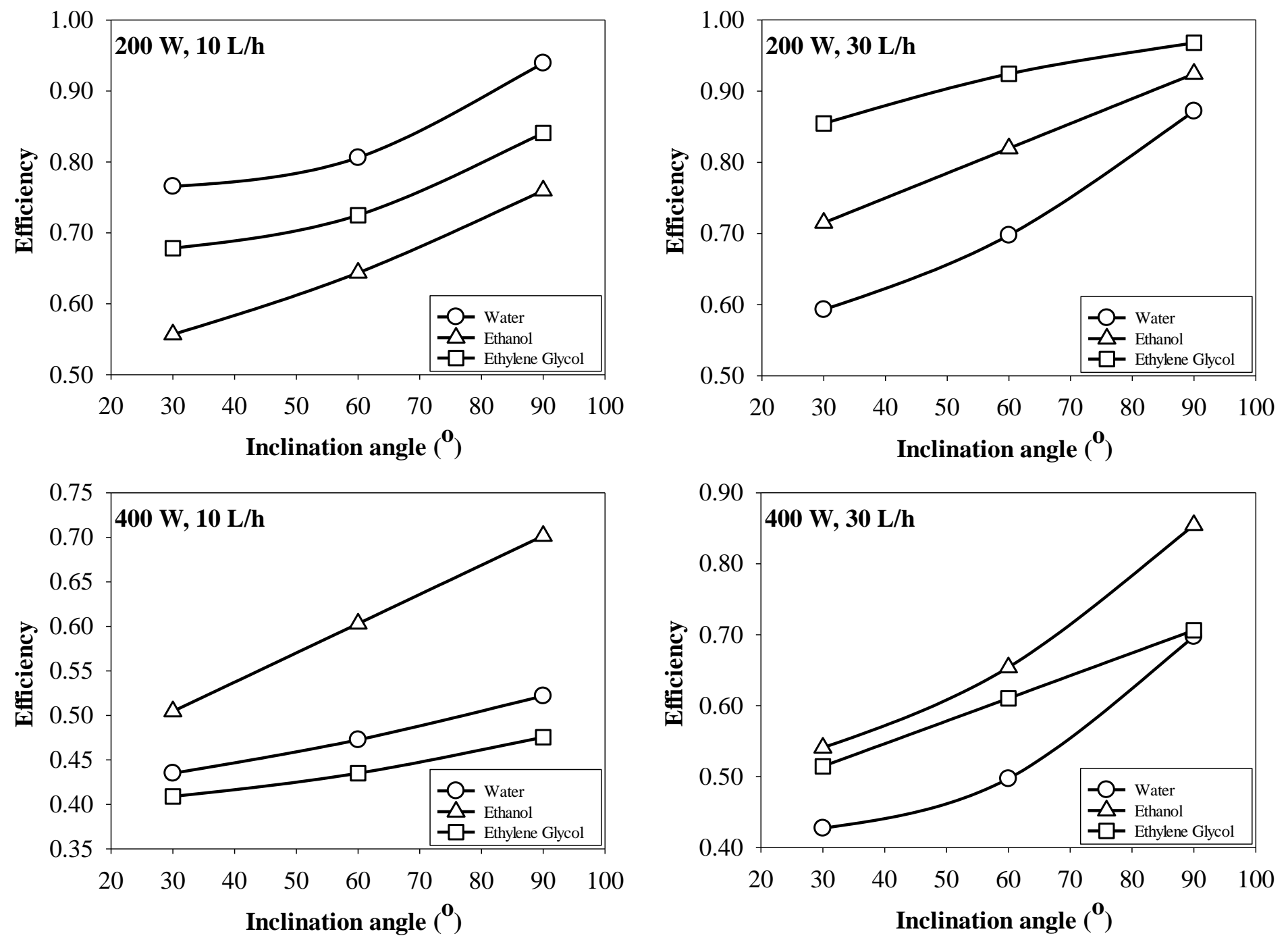

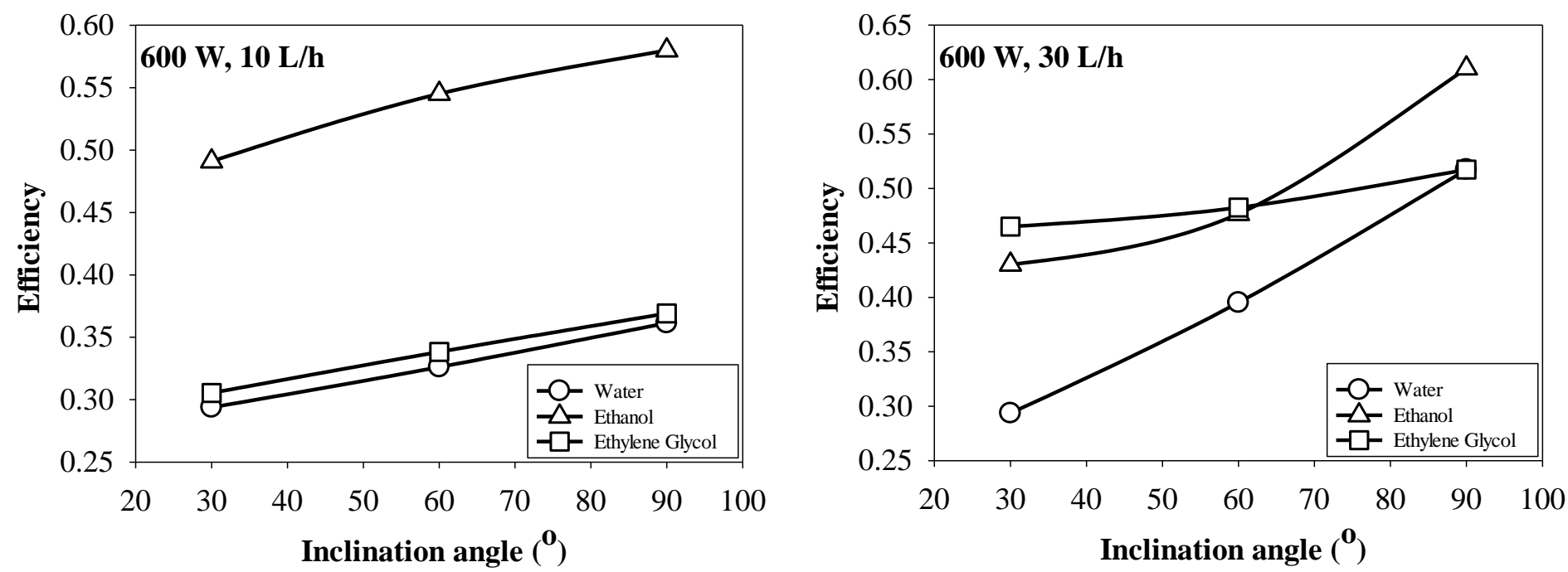

Figure 8. Efficiency of TPCT. 


\section{TABLE CAPTIONS}

Table.1 Thermopysical properties of working fluids at $20^{\circ} \mathrm{C}$

Table 2. Heat losses from TPCT.

Table 3. Comprasion of the present work with other published results for water and $90^{\circ}$ inclination angle. 
Table 1 Thermopysical properties of working fluids at $20{ }^{\circ} \mathrm{C}$

\begin{tabular}{lccclll}
\hline Fluid & $\begin{array}{l}\text { Molecular } \\
\text { Formula }\end{array}$ & $\begin{array}{l}\text { Boiling } \\
\text { point } \\
(1 \mathrm{~atm})\left({ }^{\circ} \mathrm{C}\right)\end{array}$ & $\begin{array}{l}\text { Liquid } \\
\text { density } \\
\left(\mathrm{kg} / \mathrm{m}^{3}\right)\end{array}$ & $\begin{array}{l}\text { Latent heat } \\
(\mathrm{kJ} / \mathrm{kg})\end{array}$ & $\begin{array}{l}\text { Thermal } \\
\text { Conductivity } \\
(\mathrm{W} / \mathrm{m}-\mathrm{K})\end{array}$ & $\begin{array}{l}\text { Viscosity } \\
\left(\mathrm{N}-\mathrm{s} / \mathrm{m}^{2}\right)\end{array}$ \\
\hline Water & $\mathrm{H}_{2} \mathrm{O}$ & 100 & 998 & 2455 & 0.607 & $1.002 \times 10^{-3}$ \\
Ethanol & $\mathrm{CH}_{3} \mathrm{CH}_{2} \mathrm{OH}$ & 78.37 & 800 & 846 & 0.179 & $1.1980 \times 10^{-3}$ \\
$\begin{array}{l}\text { Ethylene } \\
\text { glycol }\end{array}$ & $\mathrm{C}_{2} \mathrm{H}_{6} \mathrm{O}_{2}$ & 197.3 & 1115 & 800 & 0.258 & $1.61 \times 10-2$ \\
\hline
\end{tabular}


Table 2. Heat losses from TPCT.

\begin{tabular}{cccc}
\hline \multicolumn{2}{c}{ Experiments } & $\begin{array}{c}\text { Heat } \\
\text { losses*(W) }\end{array}$ & $\begin{array}{c}\text { Heat loss/Heating power } \\
\text { input (\%) }\end{array}$ \\
\hline $200 \mathrm{~W}$ & & 3.53 & 1.76 \\
$400 \mathrm{~W}$ & Water & 4.81 & 1.20 \\
$600 \mathrm{~W}$ & & 6.09 & 1.015 \\
\hline $200 \mathrm{~W}$ & & 3.29 & 1.64 \\
$400 \mathrm{~W}$ & Ethanol & 4.037 & 1.009 \\
$600 \mathrm{~W}$ & & 4.90 & 0.81 \\
\hline $200 \mathrm{~W}$ & & 3.78 & 1.89 \\
$400 \mathrm{~W}$ & Ethylene & 5.35 & 1.33 \\
$600 \mathrm{~W}$ & glycol & 6.61 & 1.10 \\
\hline
\end{tabular}

*Insulation thickness is 0.06 m. 
Table 3. Comprasion of the present work with other published results for water and $90^{\circ}$ inclination angle.

\begin{tabular}{lllllll}
\hline Study & $\begin{array}{l}\text { Mass flow rate } \\
(\mathbf{g} / \mathbf{s})\end{array}$ & $\begin{array}{l}\text { Filling ratio } \\
\text { (vol. of TPCT) }\end{array}$ & $\begin{array}{l}\text { Lenght of } \\
\text { TPCT }(\mathbf{c m})\end{array}$ & $\begin{array}{l}\text { Heating } \\
\text { Power input } \\
(\mathbf{W})\end{array}$ & R $\left({ }^{\circ} \mathbf{C} / \mathbf{W}\right)$ & Efficiency \\
\hline Present & $5.5(20 \mathrm{~L} / \mathrm{h})$ & $35 \%$ & 100 & 200 & 0.26 & 0.88 \\
& $5.5(20 \mathrm{~L} / \mathrm{h})$ & $35 \%$ & 100 & 400 & 0.17 & 0.61 \\
Fadhl et al.[12] & - & $50 \%$ vol.of evap. & 50 & 225.25 & 0.12 & - \\
Noie et al [29] & - & - & 100 & 195.2 & - & 0.86 \\
Sözen et.al. [34] & 5 & $33.3 \%$ & 100 & 200 & 0.23 & - \\
& 5 & $33.3 \%$ & 100 & 300 & - & 0.85 \\
& 5 & $33.3 \%$ & 100 & 400 & 0.12 & - \\
Amiri et al. [37] & 4.16 & - & 100 & 150 & 0.28 & 0.84 \\
Sözen et.al. [38] & 5 & $33.3 \%$ & 100 & 200 & 0.22 & 0.76 \\
\hline
\end{tabular}

